\title{
Post-Piledriver Re-Entry
}

D. D. Rabb

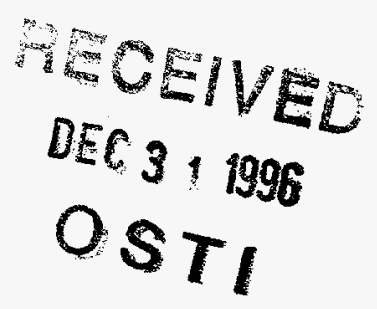

NSTHE, OW THO IOERTI IS UNLIMITED

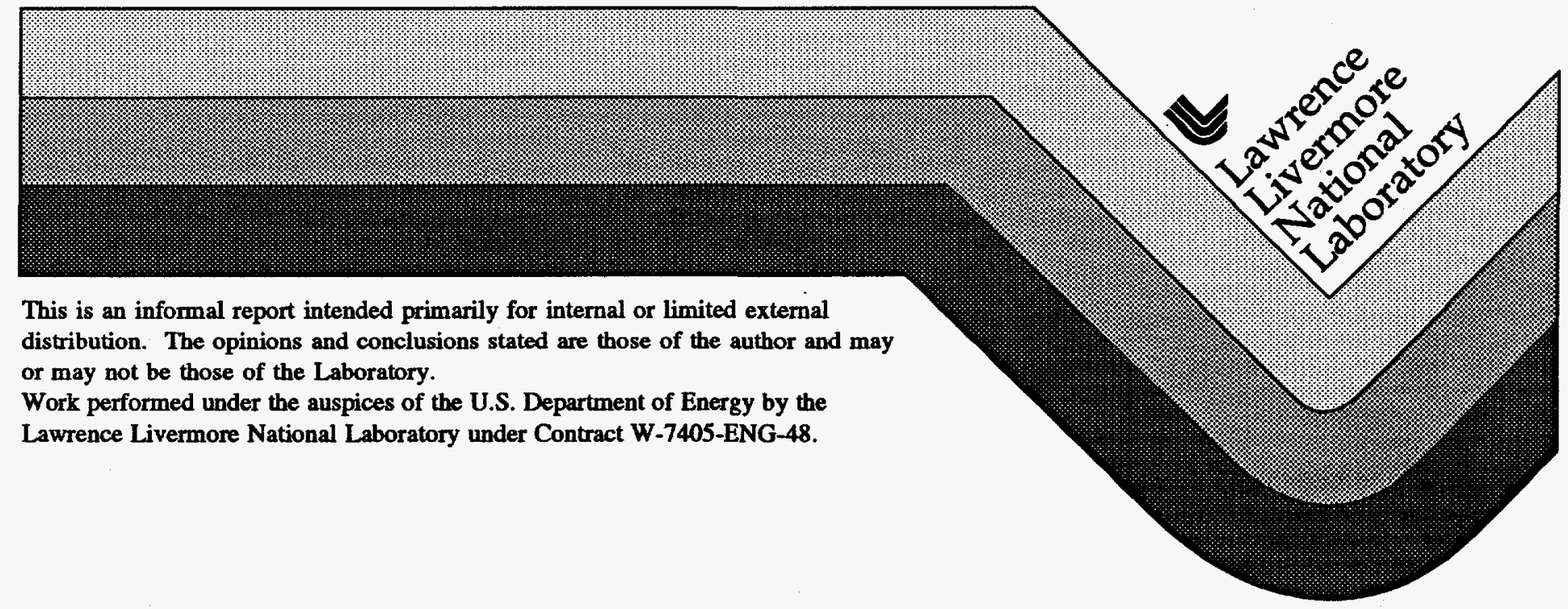




\section{DISCLAIMER}

This report was prepared as an account of work sponsored by an agency of the United States Government. Neither the United States Government nor any agency thereof, nor any of their employees, make any warranty, express or implied, or assumes any legal liability or responsibility for the accuracy, completeness, or usefulness of any information, apparatus, product, or process disclosed, or represents that its use would not infringe privately owned rights. Reference herein to any specific commercial product, process, or service by trade name, trademark, manufacturer, or otherwise does not necessarily constitute or imply its endorsement, recommendation, or favoring by the United States Government or any agency thereof. The views and opinions of authors expressed herein do not necessarily state or reflect those of the United States Government or any agency thereof. 


\section{DISCLAMMER}

Portions of this document may be illegible in electronic image products. Images are produced from the best available original document. 


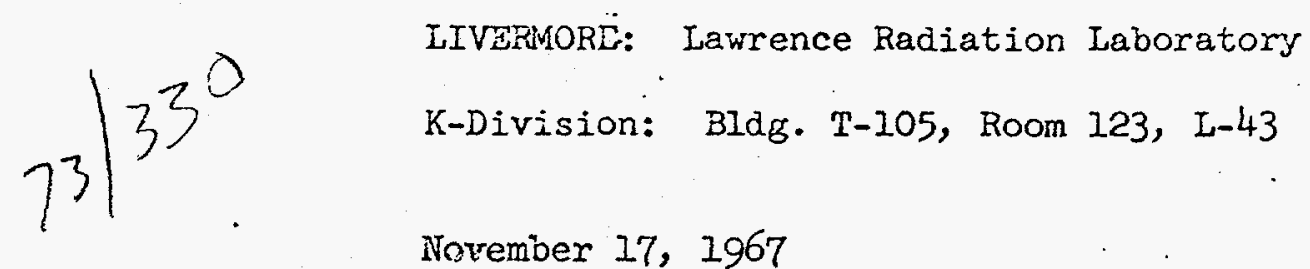

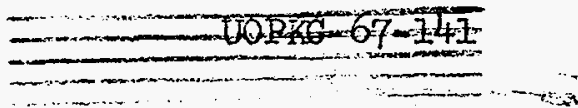

MENORANDUM FOR RECORD

TO:

Distribution

FROM:

David D.

D. Rabb

SUBJECT:

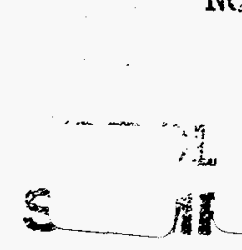

November 17, 1967

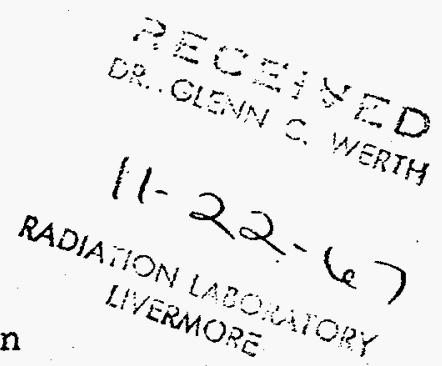

Re-Entry by DOD down the Piledriver shaft went siowly. The shaft collar had bounced so high and hard that there was a separation directly under the collar and approximately 30 feet vertically of shaft wall in that area spalled off and fell into the skip pocket. The collar area had to be packed with new concrete prior to advancing further downshaft.

\section{PHASE I. Drilling from Surface-Zero}

Since immediate post-shot geophones at Pileariver recorded "noise" for only 14 seconds, there was no certainty there had been a collapse. However, re-entry drilling lost circulation at a depth of 610 feet where a 2 -foot void was encountered. Subsequent TV camera runs and stereo pictures proved this was the top of the chimney; chimney height, 890 feet.

Pressurization tests in the hole above this point quickly reached steadystate condition, indicating very low permeability. At points below 610 feet, pressurization tests showed steady-state hole pressures were less than $0 . i$ psig, or very permeable. Drilling rates below 610 were 1 foot per minute or greater with frequent, evident voids, and complete loss of drilling fluids.

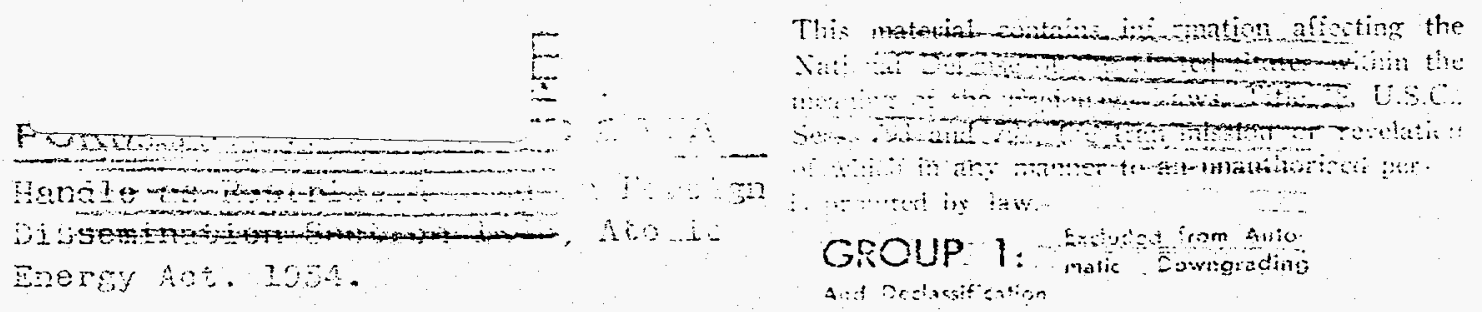


At a depth of 655 (T.D.), the drill string was pulled up 30 feet to make a connection. When an attempt was made to resume arilling, the hole was found to be caved. Since this condition coula result in loss of dxill stem and loss of the hole, it was considered advisable to suspend further drilling until after density, gamma TV and it was considered advisable to suspend further drilling until after density, gamma TV and other hole-logging surveys could be performed and a good gas sample obtained. The maximum temperature recorded in the top of the chimney was $89^{\circ} \mathrm{F}$. Gas samples indicated maximum radioactivity of $2 \mathrm{mr}$ per hour, beta plus gamma. A complete description of the Piledriver re-entry drilling work is presented by Charles Boardman in UCID-15232 (Oct. 1967 - in process). The cavity radius was predicted to be 146 feet and total void volume measured about 13 million cubic feet. When penetrated, there was a slight negative pressure in the chimney due to high barometric pressure at the surface at the time. Air in the mine during subsequent exploratory underground mining operations frequently, became high $(10 \%+)$ in $\mathrm{CO}_{2}$ and Iow $(<16 \%)$ in oxygen, with traces of monoxide. This condition seemed to be dependent upon surface barometric pressure during long shut-downs (over weekends or because of NTS test activity). A 100 cfm exhaust fan was installed to keep the cavity gas from bleeding inti underground workings.

Based on previous experience in granite at Shoal and Hardhat, the absence of an apical void and the reiatively high (900 vs. 500 feet) chimney were not expected. Because of these interesting anomalies and because: 
(1) data from Piledriver is applicable to Sloop; (2) joint occupancy with DOD during their final operation could save appreciable money, and (3) a yield determination from a Piledriver Rad-Chem sample was desired, IRI requested authorization to extend the DOD Piledriver drift toward the chimney and attempt to recover a melt sample. DOD approval and AEC authorization was given for this limited program.

Upon driving the drift approximately 20 feet beyond the $X I$ cross-cut to a point about 280 feet from over zero point, a thin vein of radioactive slag was encountered in a fissure between the top of the sand stemming and the granite back of the tunnel (Fig. 1). Naximum radiation readings, beta and gamma, were $600 \mathrm{mr}$ on contact. Chemical analysis by IASL of a sample of this glass. indicated the yield was about as expected, 61 kt plus or minus 10. In order to isolate this contaminated area, a slusher drift was started in the left rib to bypass the hot area. (Figure.2). This drift angled roughly off the main drift near the $\mathrm{XI}$ crosscut (Station 1140) for 40 feet and then ran parallel the former main arift. Muck from slusher drift read about $1 / 2 \mathrm{mr}$ on contact, probably krypton 84 and radon 222 .

The eage of the chimney (see Fig. 3) was encountered at Station 1280; therefore the apparent chimney radius at this point, about 103 feet above $2 P$, was 160 feet. The relatively solid rock forming the outsiaje of the chimney is clearly discernible, while the broken mbble inside the chimney is equally evident.

Further penetration into the chimey reached Station 1324 , 44 it insiae the chimney, $\therefore$ - the available funds ran out. Total dollars spent on the 
LRI portion was less than \$50K. DOD has driven the drift an additional 23 feet to a point 67 feet inside the chimney, and Piledrive is now completely shut down; incidentally, as a classified area.

One roughly representative, $1000-1 b$ sample was secured at a point about 10 feet inside the chimney at Station 1290; another, 60 feet inside at Station 1340. In aditition, 5 large (600-800 13) boulders were recovered as the drift progressed. These samples will undergo size analyses and radiochemical analyses of the sized fractions. Determinations will be made of $\mathrm{Sr}, \mathrm{Cs}, \mathrm{Ru}, \mathrm{Zr}-\mathrm{Nb}, \mathrm{Ce}$, and tritium.

DDR: be 


\section{Distribution:}

G. Werth, I-13

H. Reynolds, I-10

G. Higgins, I-4I

P. Moulthrop, L-35

F. Eby, I-24

J. Carothers, L-18

M. Martin, L-125

P. Randolph, L-48

M. Nordyke, I-43

J. Kahn, L-12

J. Knox, I-42

H. Tewes, I-4I

T. Cherry, L-47

S. Hansen, L-I2

C. Boardman, L-12

R. Heciman, L-437

A. Sherwood, I-437

D. Snoeberger, $\mathrm{I}-437$

I. Schwartz, I-40I

A. Prinale, $I-401$

R. Hamburger, AEC/DPNE 
$\therefore$ and

10

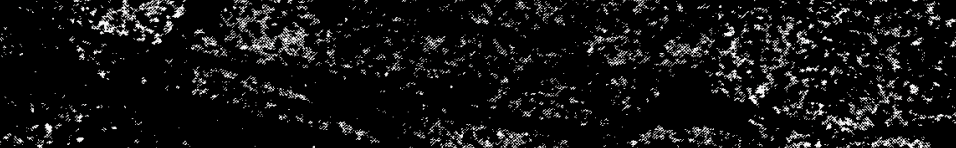

(4)

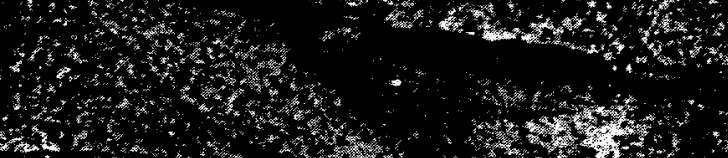

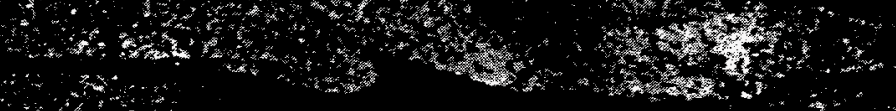

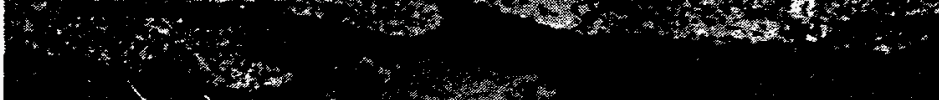

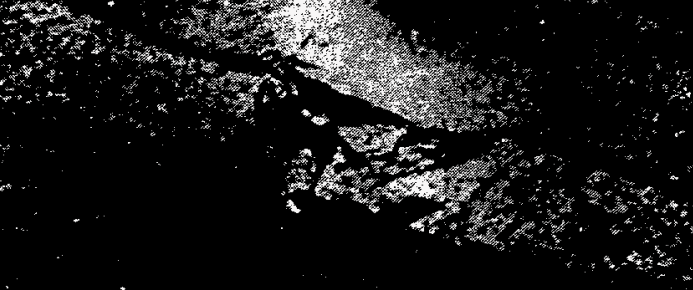

$x_{\rightarrow \infty}$

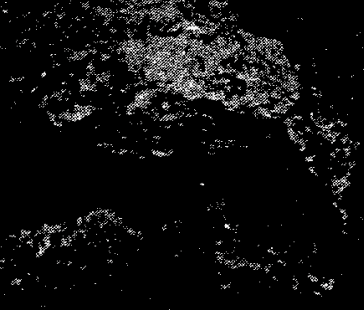

and

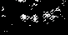
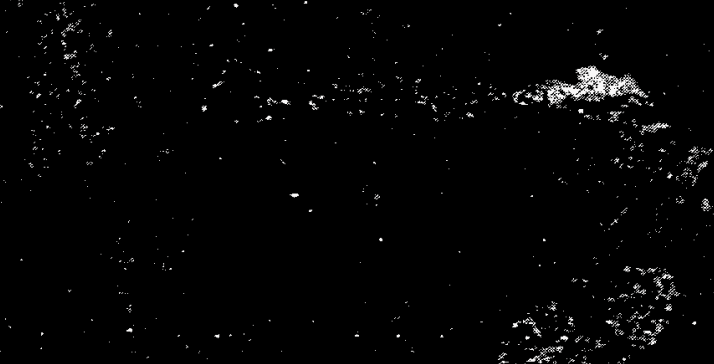

8

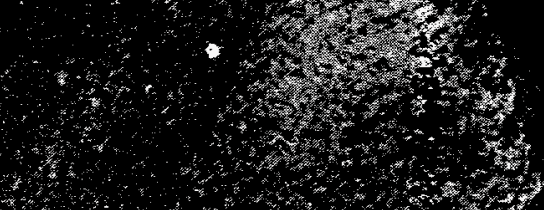

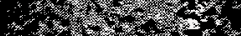

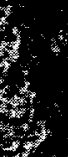

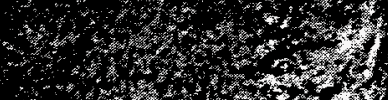

tot

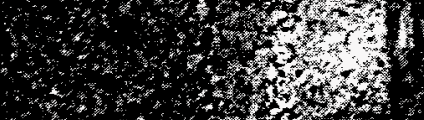

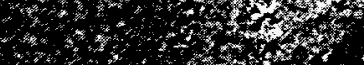

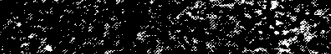

H.t. 


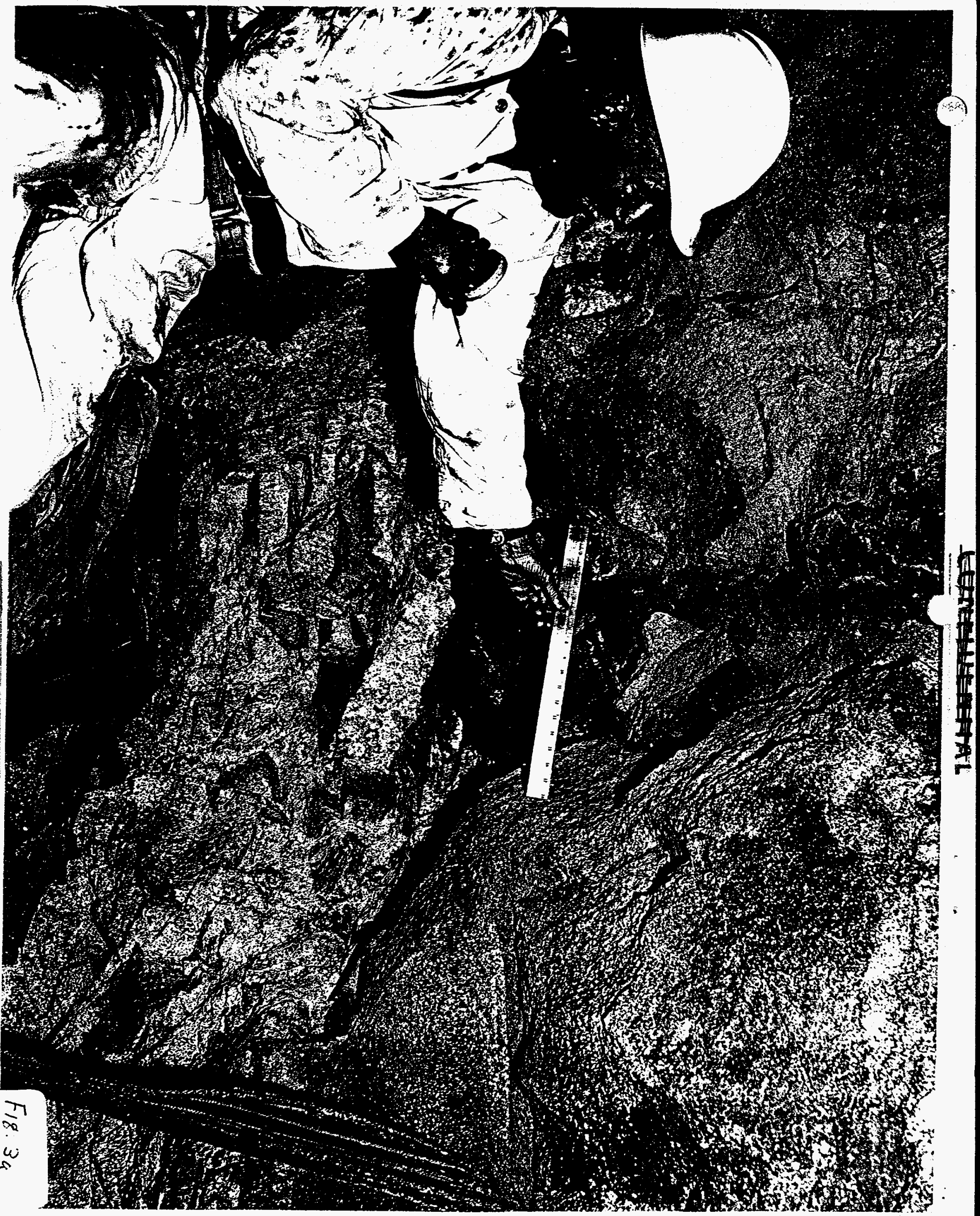




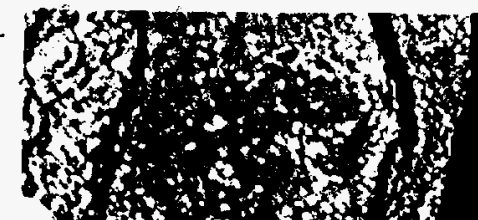

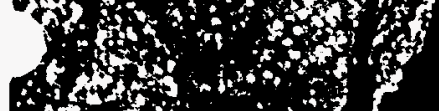

singes

P. nos

if $60+3$

If of of

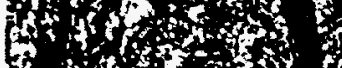

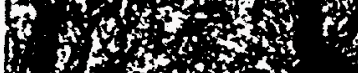

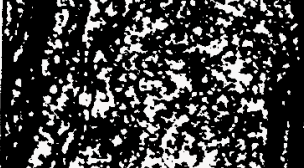

(13)

atos

(f) $18 x$

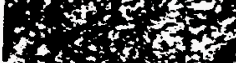

ifin

.

45

$7 x$

stis

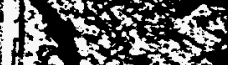

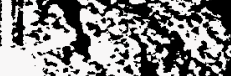

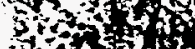

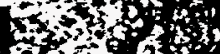

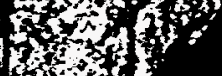

serit.

(3)

$+1$

tit

astion

然,

ond

$3 x$

sol

,

a

6

a
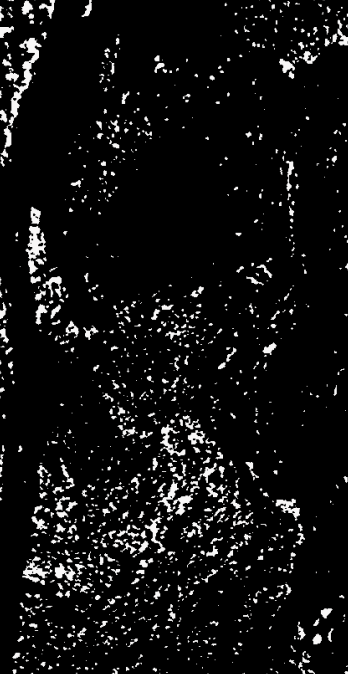

$+\infty$

6rosos

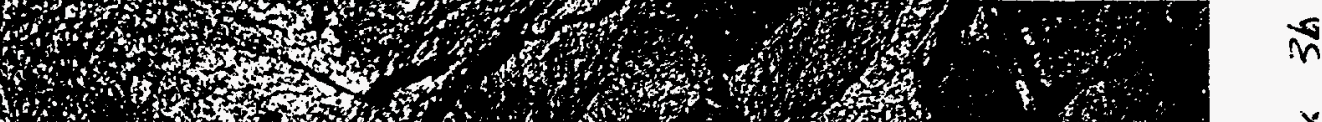

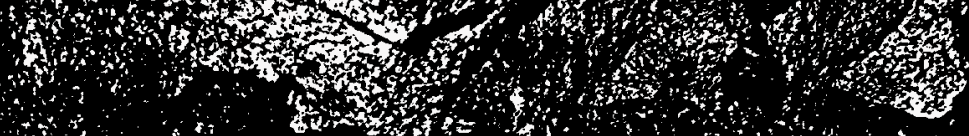

is

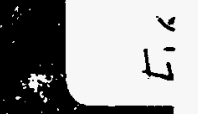
8

S 3.

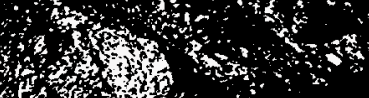

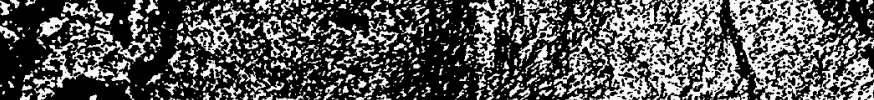

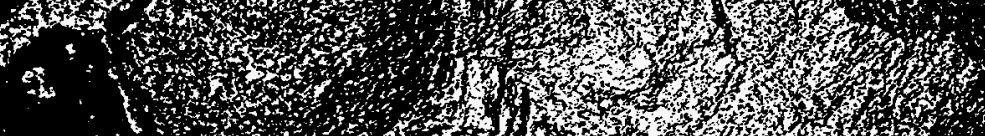

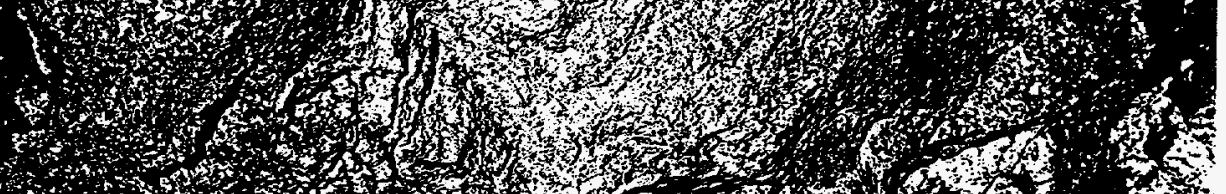

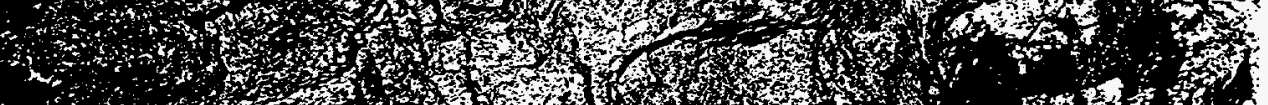

,

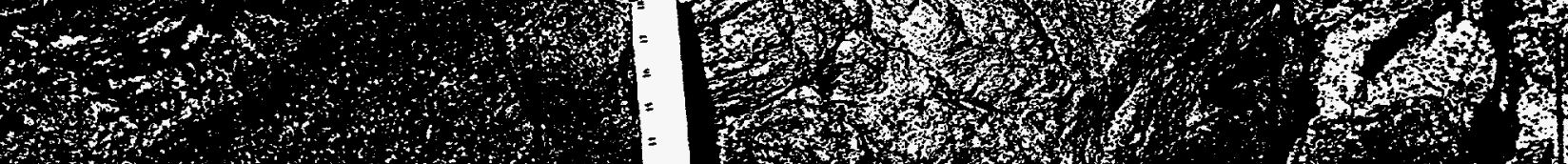

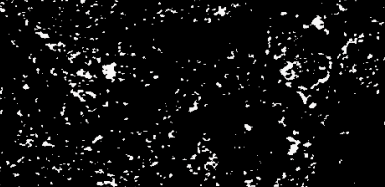

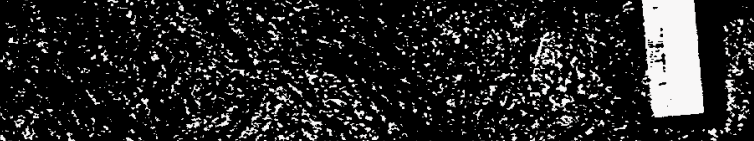
H. 3.t.

as

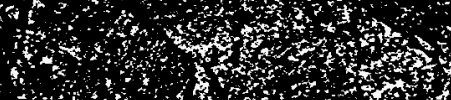

$4,4,4,5<$

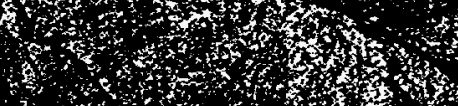

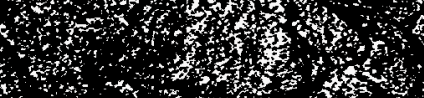

$=$
$=$
$=$
$=$

$=$

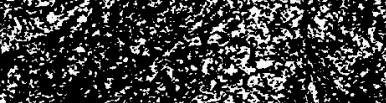
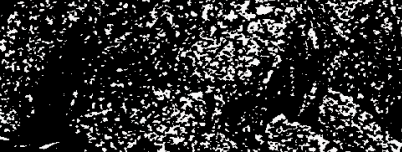

-
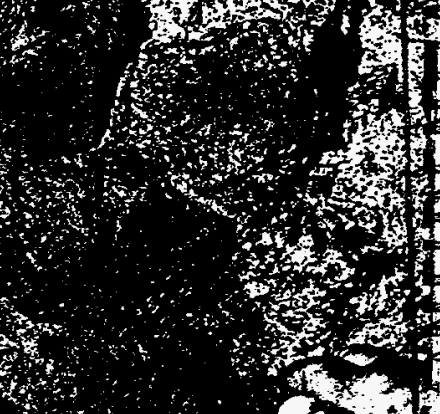

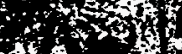

sis

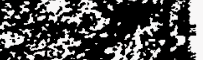
45

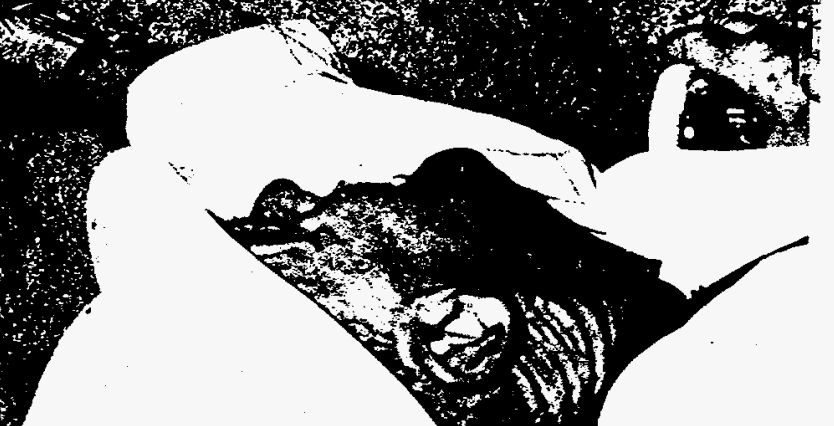

,
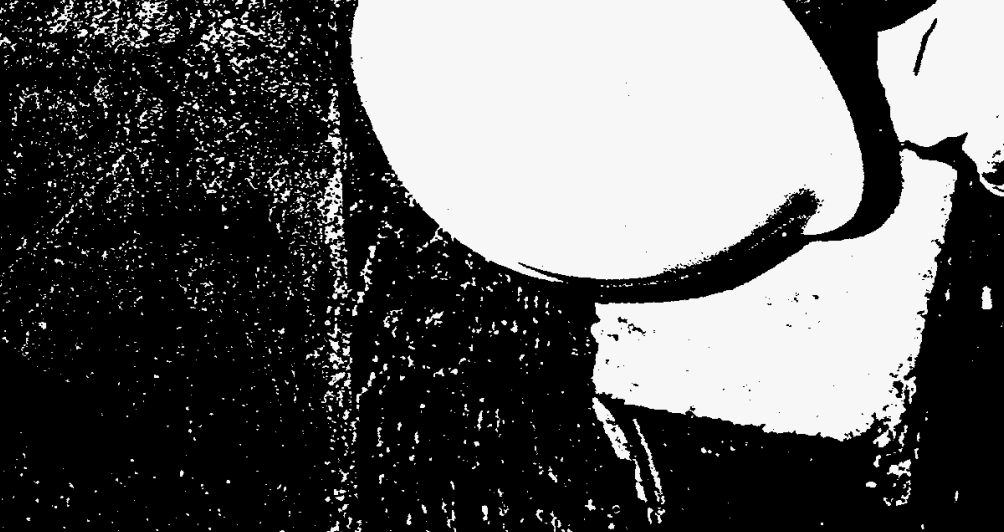

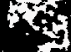

ax 